\title{
Sønderjylland 1929.
}

\section{Af Thade Petersen.}

Aarsoversigten for 1929 er i Modsætning til dem for de foregaaende Aar præget af stærkt iøjnefaldende Fattigdom paa Begivenheder i Sønderjylland, hvilket sikkert nok tør tages som et Udtryk for, at den stærke Bølgegang, i Samfundsforholdene, der maatte blive en nødvendig Følge af Restaureringen efter. Krigens Ødelæggelser og den Omordning af mange Forhold, Grænseflytningen førte med sig, nu er ved at falde til Ro. Da Oversigterne væsentlig bygger paa de Meddelelser, der gennem Aviserne er trængt ud i Offentligheden og endda har maattet indskrænke sig til kun to af disse, for ikke at gøre Arbejdet uoverkommeligt, kan de jo ikke gøre Krav paa at være udtømmende. Alligevel haaber jeg, at de maa have deres Betydning.

\section{Grænseforhold.}

Heller ikke i dette Aar har Tyskerne kunnet lade være med at tale om Grænsens Flytning mod Nord, saa tit de fandt Lejlighed til det. Saaledes udtalte Formanden, Rüss, ved et Landkommuneforbundsmøde i Flensborg den $28 / \mathrm{s}$ Haabet om, at Grænsen maatte blive flyttet igen, og tidligere Regeringspræsident Johannsen talte om "denne vilkaarligt trukne Grænse sen selv kun paafaldende sjældent og spagfær,digt gjort. sig gældende i det offentlige Liv.

En yderst uheldig Spionaffære, i hvilken en dansk Officer, Kaptajn Lembourn fra Tønder, var indviklet, endte med, at han af Rigsretten i Leipzig idømtes 5 Aars Tugthus, $\left.\left(\mathrm{H} .{ }^{10} /{ }_{1}\right)^{*}\right)$. F $æ$ r d s l e n over Grænsen lettedes yderligere ved Indførelsen af Udflugtskort, der kan løses ved Grænseovergangen for 10 Øre. $(\mathrm{H} .1 / 7)$. K or t$\mathbf{l} æ \mathbf{g} \mathbf{n}$ in $\mathbf{g}$ e $\mathrm{n}$ af Landsdelen skrider godt fremad, men vil dog tage 6-7 Aar endnu. (H. 1/11). Megen Undren vakte et Forligsforslag om at yde Tyskland $140,000 \mathrm{Kr}$. i Erstat-

*) $\mathrm{H}=$ Hejmdal 1929, Av. = Flensborg Avis 1929, L $=$ Nordslesvigsk Landbrugs- og Mejeritidende 1929. 
ning for den Vandskade, de danske Digebygninger ved Vidaaen volder tyske Grundejere, da Tyskland i Virkeligheden har større Gavn end Skade af det danske Arbejde. (Av. ${ }^{28} / 8,4 / 9$ ). De faldnes Antal opgøres til ca. 6000 . (H. ${ }^{\theta} / 11$ ).

\section{Nationalt Liv ved Grænsen.}

a) Dansk Syd for Grænsen.

Valget den ${ }^{17} / 11$ gav Danskerne Erstatning for en god Del af det Tab, de led i Maj 1928, idet de naaede 4501 Stemmer mod 2357 i 1928. I Flensborg By fik de 2931 Stemmer og 4 Mandater, i Landkredsene Flensborg, Syd Tønder og Gottorp Amt fik de henholdsvis 701, 506 og 363 Stemmer og hver et Mandat. (H. ${ }^{18} / 11,{ }^{18} / 11$. Av. ${ }^{19} / 11$ ). Den danske Menighed i Flensborg har 2536 Medlemmer. For at skaffe de fornødne Pengemidler sætter de deres Bidrag op fra 4000 til betydeligt over 8000 M. (Av. ${ }^{14} / 5$ ). D uborgskolen har 327 Elever, Skolerne i Tarup 12, Kobbermøllen 13, Jaruplund 14. De har haft et roligt Aar. (Av. 5/5). Fra Duborgskolen har nu over 100 Elever taget Realeksamen. (Av. ${ }^{24} / 3$ ). Siden 1919 er der bevilget 1200 Ansøgninger fra Sydslesvig til danske $\mathrm{H} ø \mathrm{j}-$, E f t e rog F a g s o le r, deraf 504 fra Flensborg. (H. ${ }^{22} / 1$ ). B o gsamlingen i Flensborghus har udlaant 40,799 Bind. Den ${ }^{2} / \mathrm{s}$ fandt det danske A a rsmøde i Flensborg Sted. Den slesvigske Forening i Flensborg har 3519 Medlemmer mod 3612 i 1928. I Gottorp Amt var der derimod 31 Fremgang. (H. ${ }^{3 / 8}, \mathrm{Av} .{ }^{4} / \mathrm{s}$ ). Et nyt $\mathrm{F}$ or s a m ling sh u s indviedes $5 / 1$ i Lykshorg (H. $8 / 1$ ). Den for kort Tid siden oprettede Slesvigske $\mathrm{Kr}$ editf orening har 36 Andelshavere med 5025 M. Andelskapital og 18,947 M. Indskud. (H. 2/7). Mødet paa Frøsle v Polde, der er særlig beregnet paa Besøg fra Syd for Grænsen afholdtes den $21 / 7$ og var besøgt af 3-400. (Av. ${ }^{23} / 7$ ). Ensomme g a m les $\mathrm{V}$ æ r n i København indbød 10 gamle fra Flensborg og 2 fra Slesvig til Besøg i København. (Av. ${ }^{15} / 8$ ).

b) Tysk Syd for Grænsen.

De $ø$ k onomiske Forhold Syd for Grænsen er vedblivende daarlige. I $79 \%$ af Landbrugene slaar Indtægten ikke til til Renterne (H. ${ }^{2} / 8$ ) og i Flensborg er Erhvervs- 
livet yderst trykket. (H. $\left.{ }^{14} / \mathrm{s}\right)$. Der er ikke færre end 2674 ar bejdsløse i Distriktet i den bedste Arbejdstid. (H. ${ }^{23} / 7$ ). Mange lader sig under disse Forhold henrive til $\mathrm{T}$ umulter. I Husum lavede 200-250 Landmænd Opløb paa Gaden under Retsforhandlingen mod nogle Landmænd. (H. $4 / 1$ ). Hitler og Ludendorff siges at staa bag ved slige Optøjer f. Eks. i Holsten. (H. ${ }^{7} / 1$ ).

Professor Scheel bliver i Kiel til stor Ergrelse for den nationalistiske tyske Grænsepresse. (H. ${ }^{31} / 7$ ).

"Die heimattreuen Nordschleswiger" har 27 stedlige Afdelinger i Slesvig-Holsten. (H. $13 / 7$ ).

17 Steder i Grænsestrøget Syd for Grænsen or der bygget eller indrettet tyske $\mathrm{M} ø \mathrm{~d}$ e lo $\mathrm{k}$ a l e r, til Dels sammen med Skoler. (H. ${ }^{13} / 8$ ). I Sydtønder Kreds kan kun »deutschstämmige» faa Hjælp til Bygning af egne Hjen. (H. ${ }^{18 / 12}$ ).

c) Tysk i Nordslesvig.

Det Krav, Pastor Schmidt ved Juletid 28 fremsatte i Folketinget om særlige tyske Skolekommissioner, tyske højere Skoler og større Bidrag til Privatskoler, gentog han noget efter Nytaar i Form af et Lovforslag. Undervisningsminister Byskov erklærede dog, at han ikke vilde stille de tyske Privatskoler gunstigere end de danske. (H. $20 / 2,22 / 2,23 / 2$ ). Ogsaa i Efteraaret gentog han sine Krav i Folketinget og vilde nu ogsaa have ty $\mathrm{s}$ Læreruddannelse. (H. $\left.{ }^{20} / 11\right)$. Paa de tyske Organisationers Aarsmøde kræver han endvidere Sikkerhed for, at Tyskerne faar aktiv Del i Uds t y kn ing a r bej d e t. Han sigter ogsaa dermed til en Grænseflytning. "Faar den fremmede Folkedel paa begge Sider uforstyrrede Livsbetingelser, udtalte han, saa forberedes derved bedst en ny Grænseafgørelse." (H. $\left.{ }^{10 / 12}\right)$. Imidlertid maatte han dog vedgaa, at Danmarks kulturelle Lovgivning havde givet Tyskerne mere, end han i sin Tid forlangte for Danskerne. (H. $\left.{ }^{27}, 5\right)$. Ved forskellige Lejligheder fremsatte han Udtalelser om dansk-tyske Forhold, som H. P. Hanssen i en Tale paa Lille Tønde betegnede som vildledende, uærlige og uredelige. (H. 6/s). En grov Udtalelse fremkom ogsaa Lærer R. Andersen fra Aabenraa med paa Knivsbjerg, idet han kaldte Udstykningen et Mordfor$s ø \mathrm{~g} \bmod$ Befolkningen i Nordslesvig. (H. ${ }^{1 / 7}$ ). Et Forsøg paa at hindre $\mathrm{T}$ ing levhus i at faa Bevilling mislykke- 
des. (H. $8 / 1$ ). De tyske organis ation er holdt Aarsmøde ${ }^{7 / 12}$ i Tønder. (H. ${ }^{10} / 12$ ). $\emptyset \mathrm{k} \mathrm{onomisk}$ spiller Voge lgesang en stor Rolle blandt Tyskerne. Fra ${ }_{1 / 4}^{1 / 31} / 12$ 28 ydede han 505 Laan til 3,118,333 Kr. (H. ${ }^{5} / 1,4 / 4$ ). Siden synes hans Laanevirksomhed at være bleven langsommere $i$ Vendingen. (H. ${ }^{22} / 8$ ). Han indlader sig for Resten undertiden paa overraskende Forretninger. Paa Kærgaard i Møgeltønder satte han en Besætning ind i Stedet for den pantsatte, som Ejeren havde solgt, hævdede sin Ejendomsret til den ny Besætning og købte Gaarden, da Ejeren maatte sælge den. (Av. $5 / 1,9 / 1,16 / 4$ ). Ogsaa andre Steder har han købt Kreaturer og anbragt som sin Ej e n d om paa Gaarde, han har givet Laan i. (H. ${ }^{18 / 2}$ ). Han er nu tit en haard Kreditor. Han siges at have maattet overtage $60-70$ Gaarde (H. ${ }^{4 / 4}$ ), som han lader Ejerne bestyre efter sine Anordninger. (H. ${ }^{26} / 1$ ).

De tyske $B \mathrm{l}$ a de matte endelig opgive deres Selvstændighed og smeltes sammen til et. (H. $\left.{ }^{31} / 1\right)$. I December udsendte Dr. Alnor en B og om Pastor Schmidt. Den bringer en hel Del godt Materiale, men er meget hildet $i$ sine Domme. (H. $\% / 12$ ). Paadutter H. P. Hanssen en Samtale med Schmidt, som Hanssen ikke husker. (H. ${ }^{5 / 12}$ ).

Tysk Partiagitation søgte en Tidlang Syd fra at. gribe over Grænsen. Saaledes talte Hitlers Repræsentant v. Waldow ved et Møde i Løjt. (H. $7 / 1,9 / 1$ ). Det holdt de. tyske Blade dog ikke af. (H. $\left.{ }^{8} / 1\right)$.

Støtte Syd fra tilflyder dem stadig rigelig. I Januar modtog de $3530 \mathrm{Mk}$. i Fadderskabsgaver til flere Skoler. (H. ${ }^{14} / 1$ ). I Holsten og Slesvig alene støtter 100,000 Skolebørn dem med ugentlige smaa Bidrag. (H. ${ }^{8} / \mathrm{s}$ ). Jugendspende alene indsamlede fra $1 / 1-30 / 82844,000$ Mk. og $1 / \mathrm{m}-{ }^{30} / \mathrm{s} 29$ indsamlede den $3700 \mathrm{Mk}$. i 87 Skoler. (H. $3 / \mathrm{s}$ ). 325 Elever fra Grænseomraadet har faaet Støtte af den tyske Velfærds- og Skoleforening til Besøg paa tyske Skoler. $\left(H .{ }^{11 / 3}\right)$.

Paa kirkeligt O mraad e har Fremmedmenighederne udfoldet rørig Virksomhed. Pastor Horstmann holdt 25 Gudstjenester i Sønder Vilstrup, 13 i Toftlund, 12 i Halk, 13 i Løjt, 12 i Oksenvad, 4 i Sommersted og 5 i Skærbæk og desuden 49 Menighedsmøder de nævnte Steder og i Kelstrup, Rødding og Hønning-Gaansager. (H. ${ }^{10} / 1$ ). Deres Virksomhed strækker sig til 25 Menigheder (det vil vel sige Sogne). I 20 af disse holder de Menighedsmøder. (Av. ${ }^{17 / 5}$ ). Af n y Præster kom til Wassner i Graasten 
(H. ${ }^{22} / 1$ ) og Gottfriedsen i Aabenraa, saa at der nu er 5. (H. $\left.{ }^{12}{ }_{10}\right)$.

Privatskoler var der i 2821 af med 827 Elever. Desuden undervistes 2061 Børn i tysksprogede Kommuneskoler. (H. ${ }^{15} / 1,12 / 3$ ). Privatskolen i Tinglev begyndte 1924 med 12 Elever og har nu 70. (H. ${ }^{14} / 1$ ). Flere ny er bleven oprettet (H. ${ }^{12} / 3,{ }^{12} / 4,{ }^{28} / 7,5 / 11$ Av. $\left.{ }^{14} / 4\right)$, saa at der i September 29 var 25, hvoraf 18 havde egne Bygninger. (H. ${ }^{13} / 0$ ).

Mens disse tyske Privatskoler faar aarlig ca. 18,000 Kr. i dansk Statsstøtte, faar 3 danske Privatskoler Syd for Grænsen kun 1878 Mk. tysk Statshjælp. Duborgskolen fik i 3 Aar 12,000 Mk. men nu intet. (H. ${ }^{17} / 12$ ).

Tyskerne har nu $35 \mathrm{~B} \mathrm{og} \mathrm{s} \mathrm{a} \mathrm{m} \mathrm{l} \mathrm{in} \mathrm{g} \mathrm{e} \mathrm{r} \mathrm{med} \mathrm{ca.} 23,000$ Bind, 31 Ungdomsforeninger med 1500 Medlemmer. Fremmedmenigh ederne er traadt i Arbejdsfællesskab med Menighederne i Folkekirken. 9 Efterskol e r er i Gang, og der er oprettet ny Privatskoler i Hellevad, Vilsbæk, Lydersholm og Kværs. (H. ${ }^{13} / 12$ ).

Dr. Lorenz Christensen talte i Studentersamfundet om H jemmetyskerne. (H. $\left.{ }^{15} / 4,{ }^{24} / 4\right)$ Det var den tyske politiske Ledelse ilde tilfreds med. $\left(H^{10} / 4\right)$. H. P. Hanssen talte ${ }^{20} / 4$ om dem i Studenterforeningen. (H. ${ }^{22} / 4$ ).

Af $636 \mathrm{Stemmer}$, som Tyskerne tabte ved Folketingsvalget 24/4, faldt de 453 paa de nationalt vanskelige Egne. (H. $1 / 5$ ).

d) Danski Nordslesvig.

Den 8. Juli holdt Sprogforeningen og Skoleforeningen deres Aarsmøde i Nørborg. Sprogforeningens Medlemsantal er steget fra 6288 til 8550 , deraf 6044 i Sønderjylland. Den har udsendt 13,602 Bøger og ydet $3,446 \mathrm{Kr}$. til Forsamlingshuse. Sk oleforeningen har stottet 291 fra Nordslesvig og 85 fra Sydslesvig til Skolebesøg. Den har 12,567 Medlemmer. (H. ${ }^{8} / 7$. Av. ${ }^{8} / 7$ ). Sprog fore ninge n har nu 484 Tillidsmænd (en Fremgang af 151) deraf 130 norden Aa. (H. ${ }^{22} / 1$ ). L a n d e vær n e t har ydet 104 almindelige Laan, 32 ved frivillige Handeler og 27 ved Tvangsauktion. (H. $8 / 3$ ).

Det landøkonomiske Ung d o m s a r bej d e, der 1928 begyndte i Aabenraa Amt, slog hurtig an i Haderslev Amt, hvor der ${ }^{28} / 29$ var 23 Hold med 389 Elever i elementær Landbrugskundskab. (H. $\left.{ }^{2} / 9\right)$. Det drøftedes i Graasten. (II. ${ }^{28} / 8$ ). 
Af nye Forsamlingshus e toges følgende i Brug: Padborg, som har kostet $80,000 \mathrm{Kr}$. (H. ${ }^{11} / 1,14 / 1$. Av. ${ }^{12} / 1$, 13/1), Faarhus (H. $8 / 5$, Av. $7 / 5$ ), Jyndevad (H. $7 / 6,{ }^{27},{ }_{0}, \mathrm{Av}$. ${ }^{27} / 7,8 / 8$ ) og Branderup (H. ${ }^{1 / 10}, 7 / 10$ ).

Valgene til By-og Sogneraad gav gennemgaaende gode Resultater som Følge af dansk Enighed $\left(\mathrm{H}{ }^{13}{ }_{2},{ }^{14} / 2\right.$, 18/2). I Haderslev var Danskerne lige paa Nippet til at vinde et Mandat mere (H. $\left.{ }^{13} / 3,{ }^{14} / 3\right)$, i Aabenraa vandt de et Mandat (H. ${ }^{6} / 3$ ), i Højer 2, mens Tyskerne tabte deres sidste Mandat i Skærbæk (H. ${ }^{4} / 3$, Av. ${ }^{6} / 3$ ). I Tønder derimod vandt Tyskerne et Mandat, fordi der var opstillet to socialdemokratiske Lister (H. ${ }^{9} / 3$, Av. $\left.{ }^{10} / \mathrm{s}\right)$. I Landsognene var Udfaldet $i$ Almindelighed godt. Kun vandt Tyskerne et Mandat i Burkal, Ravsted og Bylderup Sogne ( ${ }^{7} / 3^{3}$, ${ }^{8}{ }^{16} / 3$ ). Derimod fik Udbjerg dansk Flertal (Av. ${ }^{14} / \mathrm{s}$ ).

Ved Folketingsvalget tabte Tyskerne et betydeligt Antal Stemmer, 636 (H. 1/5), mens Socialdemokraterne vandt stærkt frem.

I I d ræt ten stod Kampen om Adskillelse mellem Skytter og Gymnastikere. (H. ${ }^{11} / 3,{ }^{28} / 8$ ). Samarbejdet bibeholdtes dog (H. $\left.{ }^{23} / 8\right)$.

I en lang Række Artikler giver Amtsskolekonsulent Svendsen Oplysning om Jordkampens Gang. I Haderslev Amt var der 191023 Domæner, med 3863 ha, købt for $4,170,000 \mathrm{Mk}$., for største Delen af Tyskere $\left(\mathrm{H}^{2} /{ }^{\mathbf{1}}{ }^{\mathbf{1 9} / 10}\right)$.

Historisk Samfund for Sønderjylland har 657 Medlemmer. Det giver Stødet til Rejsning af et Mindesmærke for A. D. Jørgensen i Graasten (H. ${ }^{23} / 8$ ).

Rens Efterskole har haft 41 Vinter- og 13 Sommerelever. Der blev paa den holdt 10 godt besøgte Gudstjenester og 28 nationale Møder (Av. ${ }^{12} / 10$ ). Dens Efteraarsmøde var godt besøgt (H. $\left.{ }^{20} / 10\right)$.

Bibliotekernes Bogantal er i Haderslev 7,821, Sønderborg 13,500, Aabenraa 21,102, Tønder 7,625 (H. $\left.{ }^{23} / 10\right)$. Haderslev har udlaant 47,441 Bind (H. $\left.{ }^{15} / 11\right)$. Der drøftes en Forbindelse med de andre Biblioteker i Amtet (H. $\left.{ }^{17 / 10}\right)$. Tønder har udlaant 40,676. (Av. 12/4). En Sammenslutning af Biblioteker $i$ Tønder Amt omfatter 17. (Av. ${ }^{12}{ }_{B}$ ).

${ }^{28} /$ to dannedes der en sønderjydsk T e a t e r f o r e $n$ ing ved Samvirken mellem de danske Foreninger. $\left(H .{ }^{28} / 10\right)$.

Den blaa Sang bog udkom tæt før Jul i 14. Oplag, 10,000 Eksemplarer. Den er nu trykt i ialt 78,000 Eksemplarer. (H. ${ }^{14} / 12$ ). Siden 1924 alene i 32,000. (H. $3 / 8$ ).

Som sædvanlig fejredes Afstemningsfesten og 
Gen forening s d a gen rundt om i Landet. (H. ${ }^{11}{ }^{13} / 2$, Av. ${ }^{12} / 2$ ). Genforeningsfesterne blev flere Steder særlig festlige ved Besøg af Gæster fra norden Aa. (H. ${ }^{17} / 6$ ), Av. ${ }^{17} / \mathrm{o}$ ).

Af andre Fester skal nævnes De blandede Distrikters Landboforenings 75 Aars Jubilæum den ${ }^{16} / 2$, (Av. ${ }^{15} / 2$, 10/2), Harmonien i Haderslev 80 Aarsdag, (H. 1/10, 18/10), Asserballe Ungdomsforening, den ældste sønderjydske, 25 Aarsdag (H. $\left.{ }^{3} / 10,7 / 10\right)$, Felsted Sangforening 50 Aar (H. ${ }^{12} / 11$ ).

Det sædvanlige S o m m e r m ød e i Vedsted var stærkt besøgt. (H. ${ }^{15} / 7$ ). Paa Jels Voldsted samledes 1000 Mennesker. (H. ${ }^{22} / 7$ ). Paa Rødding Højskole holdtes 3 Dages Efteraarsmøde. $\left(\right.$ H. $\left.{ }^{16} / \mathrm{s}\right)$. Efteraarsmødet i Bylderup var be søgt af 350. (H. ${ }^{23} / 9$ ).

100 Præster fra norden Aa kom i Besøg. (H. ${ }^{19} / \mathrm{e}$ ). Landboere gjorde mange gensidige Besøg. (Av. ${ }^{11} / 5,5 / 7,6 / 7$, 10/10). Til det grundtvigske Vennemøde i København $15 / 10$ gjordes ogsaa en Fællesrejse med stor Deltagelse. (H. ${ }^{24} / 8$ ).

$\mathrm{K}$ ong e $\mathrm{n}$ s aarlige Besøg fandt Sted midt i Juli. (H. $17 / 7,18 / 7)$.

I Tilknytning til et Foredrag af Seminarielærer Eskildsen fandt der en lang Drøftelse Sted af Folkem a a l e t. (H. $\left.{ }^{11},{ }^{22},{ }^{28},{ }^{28} / 10,{ }^{8}{ }^{23} / 11\right)$.

Interessen norden Aa for Sønderjylland giver sig stadig stærkere Udslag, sidst $\mathrm{i}$ en Drøftelse af $\mathrm{F}$ a d d e rskabsforeninger i Aalborg. (H. $4 / 12,5 / 12$ ).

\section{Politik.}

Folketingsvalget gav stærk Tilbagegang for Tyskerne, stor Fremgang for Socialdemokraterne. Venstre tabte ca. 300 Stemmer men beholdt sine Mandater, de konservative tabte 200 Stemmer. Sønderjylland har efter det 9 Folketings- og 5 Landstingsmænd. (H. ${ }^{25} / 4$ ).

Sønderjydske Forhold berøres især af Forslaget om Ophævelse af den særlig sønderjydske Lovgivning og af Lovforslagene om Udstykning og Anvendelsen af A u gustenborg Slot. (H. ${ }^{18} / 3_{3}{ }^{16},{ }^{24},{ }^{25},{ }^{28} / 5$ ).

\section{Samfundsforhold.}

B e f o l kn ingen er vel stadig i Vækst, men mangler dog endnu meget i Tæthed. Mens Ringkøbing Amt i 1855 
havde en Befolkningstæthed af kun 13, og Ribe Amt 16 pr, Kvadratkilometer, det førstnævnte derimod 25 i 1916 og det sidstnævnte 32 i 1920 havde Tønder Amt 21 i 1860 og kun 20 i 1921, (Av. ${ }^{27} / 4$ ). Det havde saaledes endnu ikke overvundet Nedgangen fra den tyske Tid, men var dog allerede i 1925 naaet op til 29 pr. Kvadratkilometer. 1928 fødtes der 971 Børn mod 925 Aaret før. (Av. ${ }^{31} / 5$ ). I 1929 dog kun 810, i Haderslev Amt 1237 (Medicinalber. for "Tønder og Haderslev Amter).

Haderslev var ${ }^{5} / 11$ vokset med 61 , (H. $\left.{ }^{7} / 12\right)$, Aabenraa med 21, (H. $\left.{ }^{6} / 12\right)$, Sønderborg med 1, (H. $\left.{ }^{6} / 12\right)$, Tønder havde tabt 89 af de rigelig 600 , den havde vundet siden 1921. (Av. ${ }^{15} / 11,{ }^{28} / 11$ ). Mens Antallet af Skolebørn nu er i god Vækst, begynder Konfirmandantallet at dale som Følge af, at der i Krigsaarene fødtes 6671 Børn færre end normalt. (H. ${ }^{12} / 12$ ).

Siden Genforeningen er der oprettet over 400 Husmandsbrug og 80 nye smaa Gaarde. (H. $1 / 1$ ). Der fortsættes stadig med Udstykningen. (H. $\left.{ }^{25} / 3,{ }^{29} / 5\right)$. Der blev bevilget 10 Millioner $\mathrm{Kr}$. til Opkøb af Jord i det Øjemed (H. $\left.{ }^{5},{ }^{8},{ }^{14},{ }_{13}^{18}\right)$ og for en Del af dem købt 1000 ha. (H. ${ }^{22} / 10$ ). Til Foraaret agtes 150 Brug oprettet (H. ${ }^{23} / 12$ ) og der fremsattes i December et nyt Forslag om Udstykning. (H. ${ }^{13} / 11$ ). Chr. E. Christensen anker over, at det vil skabe Statsfæste, og Pastor Schmidt paastaar - med Urette at Tyskerne tilsidesrettes (H. ${ }^{5 / 7} / 7$ ). Aabenraa udlægger 50 Havelodder ved Tonder Landevej (H. $\left.{ }^{15} i s\right)$.

Muns der ved Nytaar 29 var 782 a rbejdsløse i Haders!:v, 7\%6 i Aabenraa og 178 i Tønder Amt (H. $5 / 1$ ), var disse Tal $1 / 7$ dalet til henholdsvis 249, 281 og 26 (H. ${ }^{8 / 7}$ ). Ved den T'ic! var Tallet i Sønderborg Amt 474 (H. $\left.{ }^{13 / 7}\right)$. I Haderslev Bv soges der at bøde paa Arbejdsløsheden ved en Bevilling af $100,000 \mathrm{Kr}$. til $10 \mathrm{pCt}$. Tilskud til Arbejdsløn $\left(H .{ }^{17} / \delta,{ }^{21} / \varepsilon\right)$. I Tønder sysselsættes en Del arbejclslose ved at grave Plantehuller paa de 60 ha, Byen har krabt af Abild Hede til Tilplantning (Av. 1/10). I December val Arbejdslosheden igen steget til 994 i Haderslev, Aabenraa og Tonder Amter og til 757 i Sønderborg Amt (H. 14/12).

Et stort su ndhedsmæs ig t Fremskridt var begyndt i 1928 med Oprettelsen af $\mathrm{Tuberkulose-}$ stationer. I Januar 29 aabnedes en saadan i Haderslev som den foreløbig sidste $i$ Sønderjylland (H. ${ }^{10} / 1$ ). Paa alle 4 Stationer var Antallet af Konsultationer ; 
1928 og 291739 (Ber. fra Tuberkulosestationen). I Tønder findes Tuberkulose hos 63,5 pCt. af Slagtekøer. Ogsaa i Nørborg og Augustenborg findes der høje Procenttal (H. ${ }^{18} / 11$ ). ${ }^{14} / 12$ stiftedes for hele Landsdelen en Forening til Bekæmpelse af Kvægtuberkulose (H. $\left.{ }^{16},{ }_{12}\right)$. Til $\mathrm{K} \mathrm{ræf-}$ tens Bekæmpelse dannedes der ${ }^{18 / /}$ en Forening for Haderslev Amt. (H. $\left.{ }^{20} / 8\right)$. Udvidede S y gehuse kunde tages i Brug: Haderslev Amtssygehus med nu 123 Pladser (H. $\left.{ }^{18} / 2\right)$, Byens (H. ${ }^{19} / \mathrm{o}$ ) og Gram (H. $\left.{ }^{28 / 6}\right)$.

Et $\mathrm{S}$ indss y ehospit a l bliver nu indrettet i Augustenborg Slot $\left(\mathrm{H}^{8}{ }^{8 / 2},{ }^{8} / 2\right)$ og en A and s s vage a nst alt i Løgumgaard toges i Brug. (H. ${ }^{30} / 8,{ }^{31} / \mathrm{s}$ ). 30 Foreninger findes $i$ en Sammenslutning af sønderjydske Sygeplejeforeninger. (Av. ${ }^{8 / 8}$ ).

Centralforeningen af $\mathrm{S}$ y g e k a s e $\mathrm{r}$ i Sønderjylland har 74,412 Medlemmer i 105 Kasser. (H. ${ }^{31} / 7$ ). Den statsanerkendte Sygekasse i Haderslev ophæver den bemidlede Afdeling og overviser dens Medlemmer til Sygeforsikringen "Sønderjylland «. (H. $\left.{ }_{1 / 9}^{3}\right)$.

Den alsiske $\mathrm{Br}$ a nd forsikring for Bygninger havde i 1879, da den begyndte, 2,7 Millioner Forsikringssum, nu 70 Mill. (H. ${ }^{18} / 2$ ). Den alsiske Brandforsikring for Løsøle har i 1928 udbetalt 113,000 Kr. i Brandskade. (H. 21/3). Den nordslesvigske Brandforsikring for Bygninger havde 45,000 Underskud. (H. ${ }^{23 / 10}$ ). Den nordslesvigske Brandforsikring for Løsøre har ligeledes haft store Brandskadeserstatninger og maa slutte sig sammen med "Jydsk Løsøre«. (H. $\left.{ }^{25}{ }_{s}\right)$. Der findes nu 40 frivillige $\mathrm{B}$ randvær n med 1513 Medlemmer. (H. ${ }^{8}$ ). H a gl s k a d e f orsikringe $n$ har 3081 Medlemmer. 95 led Haglskade i 1928 og fik $14,375 \mathrm{Kr}$. udbetalt. (H. ${ }^{10 / 2}$ ).

I Sønderborg skal der bygges et A I d e r dom $\mathrm{shjem}$ for $158,000 \mathrm{Kr}$. (H. $\left.{ }^{10} / \mathrm{p}\right)$. J. P. Nielsen kræver F a t tig$\mathrm{h} j æ \mathrm{I} p$ e $n$ i Sønderjylland eftergivet. (H. $7 / 12$ ).

Der findes i Sønderjylland $597 \mathrm{~B} \mathrm{e} \mathrm{vartang} \mathrm{e} \mathrm{r}$ mod 5447 i hele Landet.

\section{Erhverv og Okonomi.}

a) L a n d b r ug.

Det store Afvandings foretagende paa Tønderegnen kræver nye Tilskud, da flere Arealer er bleven draget med ind under det. (H. ${ }^{16} / 5$ ). Der er bygget 10 Pumpevarker, som kan pumpe 10 Millioner Liter Vand ud i 
Timen. (Av. ${ }^{21} / \mathbf{o}$ ). Der pløjes allerede nu meget i Engene. (Av. ${ }^{8} / 11$ ). I December skete der dog endnu Oversvømmelse. (Av. ${ }^{13},{ }^{14},{ }^{24},{ }^{28} / 12$ ). Arbejdet med S e jer s bæklavningen blev færdig allerede i Efteraaret 28. (Av. ${ }^{19} / \mathrm{s}$ ). Det kommer 1000 ha til gode og har allerede vist. sig at virke gavnligt. (Av. ${ }^{20} / 8$ ). Der tænkes nu ogsaa paa Regulering af $\mathrm{Brede} \mathrm{Aa}$ og Afvanding af Lavningen ved den. Aaens Løb vilde derved forkortes med $4685 \mathrm{~m}$. og Arbejdet vilde koste $390,000 \mathrm{Kr}$. Det menes derfor at. blive for dyrt. (Av. ${ }^{8} / 3,8 / 5$, Av. ${ }^{20} / 11$ ). I Tønder Amt er der nu $i$ det hele siden Genforeningen udarbejdet $500 \mathrm{D} \mathrm{r} æ-$ $n$ ing spla ner for mere end 3000 ha, og Størstedelen af dem er udført $\left(A v,{ }^{28} / 2\right)$. I Haderslev Amt er der udarbejdet og omtrent udført 510 Dræningsplaner for 4115 ha til et Beløb af $1,200,000 \mathrm{Kr}$. og udført eller beregnet $75 \mathrm{~V}$ a n dstandsreguleringer over $250 \mathrm{~km}$. De kommer 4500 ha tilgode og vil koste $650,000 \mathrm{Kr}$., men det vandlidende Areal var ogsaa i 192425,000 ha $\left(H .{ }^{18} / 8\right)$. Mange yderligere Kultiveringsforsøg er bleven foretaget $i$ disse Aar. En hel Række af saadanne skildres (Av. $8 / 11$ og en Række følgende Numre). Ogsaa M erglingsfor et a g e n d er er flere Steder planlagt og sat i Gang, saaledes paa Vestkysten (Av. ${ }^{24} / 2$ ), Løgumklosteregnen (H. ${ }^{3 / 11}$ ) og Vojens (H. 12/12, 24/12). Haderslev Amtsbaner besørger Udkørsel af Mergelen (H. 1/12).

Ved Jordfordelingskommissionens Hjælp er der bleven a rronderet 3000 ha og oprettet ca. 100 nye Brug ( $\mathrm{H}$. ${ }^{26} / 1$ ). Daarlig Arrondering forringer en Ejendoms Ydeevne (H. $5 / 11$ ).

Sønderjyllands $\mathrm{K} v æ \mathbf{g} b$ e $\mathrm{s}$ t $\mathbf{n}$ ing e r udgjorde i $1928261,000 \bmod 247,000$ i 1927. Deraf udgjorde Køerne, der 1925 kun var 96,000 og $1927 \quad 105,000$ i $1928 \quad 108,000$. 29,534 kontrollerede Køer gav gennemsnitlig $3288 \mathrm{~kg}$ Mælk med 3,50 \% Fedt og 131,1 kg Smør. Af Kontrolforeninger erder nu 88 med 31,756 Køer (H. $\left.{ }^{7} / 1,{ }^{10} / 10\right)$. I Løbet af 1929 . voksede Besætningerne yderligere til 263,000 , hvoraf 110,000 . Køer, hvis Antal dermed er steget $30 \%$ siden Genforeningen, $2 \%$ i Løbet af 1929, mens Mælkemængden steg $7-8 \%$ (L. 1930 S. 1 og 12).

Under Fællesledelsen af $\mathrm{K}$ orthornsavl virker 53 Kontrolforeninger med 1295 Besætninger paa 20,346 Køer (H. ${ }^{22} / 1$ ). Mælkemængden er gennemsnitlig $3294 \mathrm{~kg}$ med $3,61 \%$ Fedt. Smørudbyttet er 132,7 kg (L. S. 811). Fællesledelsen af Avl af rødt dansk Malkekvæg har 35 
Kontrolforeninger med 11,411 Køer (II. ${ }^{23} / 1$ ). Det sønderjydske Korthorns øk o n o m is k e Resultat er bedre end det rorte og det hollandske Kvægs, skønt det giver mindre Mælk og Smør, nemlig kun $126 \mathrm{~kg}$ Smør mod de fynske Kontrolforeningers $159 \mathrm{~kg}$ (H. ${ }^{15 / 2} / 2$ ). I det hele viser Kontrolforeningernes Regnskaber, at der er opnaaet gode -Resultater (H. ${ }^{1 / 11},{ }^{6} \cdot 11,8 / 11$ ). Fremavl af rødt dansk Malkekvæg vil i Haderslev Amt blive drevet i Samarbejde med de gamle Foreninger (H. $\left.{ }^{3 / 12}\right)$. Fællesledelsen af Korthornsavl kan notere 132,7 kg Smør pr. Ko mod 126,2 i ${ }^{27} /$, og 106,5 i 1920 (H. ${ }^{11} / 12$ ).

En Hindring for vor Kvægavl var det, at Tyskland ønskede at indskrænke sin Ind førsel af dansk Kvæg. Det maatte især ramme Vestkysten (H. $\left.{ }^{11} / 7,{ }^{24}, 8\right)$. Forhandlinger om det førte til en Henstilling om frivillig dansk Indskrænkning af Udførslen i Efteraarsmaanederne ( $H$. $\left.{ }^{20} / 8,29 / 8,2 / 8,4 / 8,5 / 8\right)$. O k s e b r e m se n volder endnu store Tab hernede. 1928 var $23 \%$ \% af Huderne beskadiget af den, mens hele Landet kun har $6 \%$. (L. S. 250). Et Fremskridt var der dog fra 1927, da der fandtes $31 \%$ beskadigede Huder. (H. ${ }^{21} / 1$ ).

Den vigtigste Gren af Kvægavlen er jo $\mathbf{M} æ l \mathrm{k}$ e bruget. Køernes Antal stiger som ovenfor næunt jæunt godt, men dog ikke stærkere, end at Stigningen her i 1928 kun udgjorde 23,6 \% mod Nørrejyllands 29,2 \%. Dog var den næsten dobbelt saa stor som Øernes $12,5 \%$. (L. S. 81). Deres $\mathrm{Yde}$ evne stiger ogsaa lidt men ikke jævnt. (H. $7 / 1,11 / 12)$.

Rødekro M e j e r i, der er bleven nybygget efter 40 Aars Bestaaen, er nu det største og bedst indrettede i Nordslesvig. (H. ${ }^{23} / 8,{ }^{16} / 10,{ }^{9} / 11$ ). Der findes nu i det hele 143 Mejerier her, hvoraf de 127 er Andelsmejerier. Disse er alle paa et nær Medlemmer af Mejeriforeningen, der ogsaa omfatter 6 af Fællesmejerierne. (L. S. 285). Siden Genforeningen er 8 Mejerier bleven nybygget, 23 af de gamle har foretaget større og 36 mindre Ombygninger, der tilsammen har kostet 3 Millioner Kr. (L. S. 283), 134 af Mejerierne har i 1928 bearbejdet 262 Mill. kg Mælk mod 242 Mill. Aaret før. (L. S. 127). Med Hensyn til Mælkebedømmelse staar Sønderjylland i Spidsen for hele Landet med $90 \%$ af sine Mejerier. (L. S. 204).

Mejeriernes Produktion er stigende. (H. ${ }^{11} / 11,{ }^{12} / 11$ ).

Ved en Bøtteudstilling $i$ Haderslev $15 / 1$ viste det sig, at 7 Mærker af $\mathrm{S} m ø \mathrm{r}$ et havde over 12 og kun 2 under 10 
Points. Det var den fineste Udstilling hidindtil. Ved Mejeriudstillingen i København blev Haderslev Amt Nr. 3, Aabenraa Nr. 10, mens Sønderborg og Tønder Amter laa. lavere. (H. ${ }^{8} / 2$ ). Deltagelsen hernede fra, 199 Smørmærker, var den største hidindtil. (L. S. 109). Ved Laboratoriets Bedømmelser laa Sønderjylland 1928 0,1 Points under Gennemsnittet for hele Landet. Haderslev Amt havde ganske. vist 0,1 Point ove $r$ dette, Sønderborg Amt endog 0,2 , men Aabenraa og Tønder Amter trak nedad med henholdsvis. 0,3 og 0,6 Points, u n d e r Gennemsnittet. (L. S. 28). I 1929 var der saa vidt Fremgang, at Sønderjylland kun var 0,05 under Landsgennemsnittet. Det var Aabenraa og Tonder Amter, der havde bedret sig saa vidt, at de kun var henholdsvis 0,2 og 0,3 Point under, mens de to andre Amter holdt Stillingen fra 1928 (L. 1930. S. 28).

$\mathrm{S} m ø \mathbf{r h a n d e l e n}$ er for den væsentligste Dels Vedkommende foregaaet gennem de tre Smøreksportforeninger. Den nordslesvigske, hvis Omsætning i de 25 Aar, den har bestaaet, er steget fra 972,000 Mk. til 10 Millioner Kr., har i 1928 solgt 58,078 Tønder Smør (H. $\left.{ }^{25} / 10,{ }^{20} / 10\right)$, Sønderjydske Landmænds har omsat 62,558 Dritler (H. ${ }^{18} / 11$, ${ }^{25}{ }_{11}$ ), og Haderslev Smøreksportforening $10 \%$ mere end Aaret før, omtrent 24,000 Dritler (H. $8 / 11$ ).

Graasten S lag te ri slagtede i $1928 \quad 58,333 \quad \mathrm{~S}$ vin. Det har nu 877 Andelshavere (H. ${ }^{7 / 1},{ }^{16} / 2$ ). Vojens har 870 Andelshavere og slagtede 23,834 Svin (H. ${ }^{13} / 2$ ), Aabenraa. 68,814 (H. ${ }^{14} / 2,{ }_{12}^{18}, 3 / 12$ ). Rødding 30,000 (H. ${ }^{18} / 2$ ), Sønderborg 60,855. Det havde et Nettooverskud af $215,782 \mathrm{Kr}$. (H. ${ }^{2 / 3}$ ). Skærbæk 25,305 med 24,271 Kr. Overskud (H. $\left.{ }^{21} / \mathrm{s}\right)$. Bylderup-Bov 21,511 med 37,256 Kr. Underskud (H. ${ }^{22} / 3$ ). Ogsaa. det $\mathrm{i}$ Tønder har haft et godt Aar. Det har slagtet 1\%,926; Svin og giver $8 \%$ Udbytte (H. ${ }^{12} / 3$, Av. ${ }^{10 / 3}$ ).

Smaaskovsforeningen i Aabenraa og Sønderborg Amter har nu 221 Medlemmer.

Forrentningsprocenten for 63 Ejendomme i Aabenraa Amts Landboforening blev gennemsnitlig 5,3.

Graasten Landbrugsskole havde ${ }^{20 / 30} 100$ Elever (H. ${ }^{29} / 7,4 / 11$ ).

$\mathrm{Sa}$ a r bejdet mellem Landboforeningerne begyndte allerede 1854 med et fælles Landbomøde. Først. 1893 oprettedes dog Nordslesvigsk Fælleslandboforening(L. S. 242). 
b) Industri og Ha and vær k.

I Juni fandt en Udstilling Sted i Haderslev. Den gav et godt Billede af, hvad sønderjydsk Industri og Haandværk kan yde (H. ${ }^{22} /$ ). Den blev ogsaa saa godt besøgt, at den gav et Overskud af $7000 \mathrm{Kr}$. (H. $\left.{ }^{22} / 6,{ }^{3} / 7,{ }^{14} / 11\right)$.

Haderslev Slotsvandmølle gav et Bruttooverskud af 28,000 , der brugtes til Dækning af tidligere Underskud og til Reservefond (H. ${ }^{20} / \mathrm{o}$ ). Tønder M a rgarinef a brik har 10,794 Kr. Overskud (Av. ${ }^{15} / 3$ ).

Højspændingsværkets Produktion var i ${ }^{28} / \mathfrak{g 9}$ $8,884,150 \mathrm{kwh}$, dets Overskud 418,000 Kr. Af Gælden har det hidindtil afskrevet $1,781,000 \mathrm{Kr}$. $\left(\mathbf{H} .{ }^{6} / 6\right)$. Produktionen var i ${ }^{29 / 30} 9,6$ Mill. kwh mod 5 Mill. i ${ }^{24} / 25$ (H. ${ }^{10 / 10}$ ). I T y rstrup Herreds Selskab steg Forbruget med $7000 \mathrm{kwh}$ til Lys og 10,000 til Kraft (H. ${ }^{23} / 3$ ), i $S ø$ nderborg og A a benra a Amters Elektricitetsforsyning brugtes 2,880,281 kwh. Det har $414 \mathrm{~km}$ Ledning til Højspænding, $764 \mathrm{~km}$ til Lavspænding, foruden $6 \mathrm{~km}$ Jordkabel og $178 \mathrm{~km}$ Stikledning (H. $1 / 6)$. "Sønderjyllands V e s tk y s t" har $217 \mathrm{~km} \mathrm{Høj-} \mathrm{og} 365 \mathrm{~km}$ Lavspændingsledning. Det har i ${ }^{28} / 28$ solgt $767,327 \mathrm{kwh}\left(\mathrm{H} .{ }^{11 / 6}, \mathrm{Av} .{ }^{13} / 6\right)$. M id tsønde r j y l lands Selskab har $193 \mathrm{~km}$ Høj- og $371 \mathrm{~km}$ Lavspændingsledning. Det solgte $632,272 \mathrm{kwh}$ (H. ${ }^{13 / 6}$ ).

\section{e) Handelog Skibsfart.}

Skibsfarten led i Begyndelsen af Aaret meget under Is spærringen, der først midt i Marts begyndte at slappes saa vidt, at man kunde vente Hjælp ved Isbrydning (H. ${ }^{14} / 3$ ). Snart derefter kunde Skibsfarten begynde igen (H. ${ }^{15} / 3$ ). Af Danmarks $1828 \mathrm{Sk}$ ibe paa over 20 Tons hører kun 87 eller $1,6 \%$ hjemme i Sønderjylland, og i vore Havne er der kun indladet - og ligeledes udlosset $-3,7 \%$ af al dansk Vareladning (H. $\left.{ }^{1 / 3}\right)$. Trafikken er alligevel livlig, idet de sønderjydske Havne har 6,2\% af dansk Skibs a $n$ tal $\mathbf{i}$ fri Trafik og ca. 15,9 \% af Skibe, der indkommer i Rutetrafik. Ialt indgik der Ladninger til 432,345 Tons og udgik 158,384 Tons (H. ${ }^{14} / 3$ ). Af vore Havne har Aabenraa den største indgaaende Varemængde og den største Tonnage i fri Trafik, Sønderborg derimod i Rutetrafik. Den største Udførsel har Graasten, med Egernsund $\left(\mathrm{H} .{ }^{10 / 3},{ }_{3}^{30} / 5\right)$. Haderslev begynder en ny Udvidelse af sin Havn som Nødarbejde (H. $\left.{ }^{16} / 10,8 / h_{1}\right)$. Aabenraa Søfarts Historie blev udgivet af Kaptajn Schlaikjer (H. ${ }^{20} / 12$ ). Ved 
Aabenraa Havn bygges en $\mathrm{B}$ a $\mathrm{n}$ a $\mathrm{n}$ mod $\mathrm{n}$ ing s a $\mathrm{n} \mathrm{stalt}$ (H. $\left.{ }^{14 / 1}, 18 / 4\right)$.

I Haderslev findes følgende Antal Forretninger: en gros 44 med 272 Personer og 28 Mill. Omsætning, 15 Agenturer med 31 Personer og 4 Mill. Omsætning, 387 Detailforretninger med 772 Personer og 30 Millioner $\mathrm{Kr}$. Omsætning $\left(\mathrm{H},{ }^{2} / \mathrm{s}\right)$. Eksportstaldene i Aabenraa udvides til 100 Kreaturer mere (H. $7 / 12$ ).

Fisk eriet har været i Fremgang paa næsten alle Pladser (H. $/ 11$ ).

d) Pengevæsen.

I B a $\mathrm{n}$ k e r n e $\mathrm{s}$ Virksomhed har der været Fremgang. Tondernbank gav $9 \%$, Jels Bank $7 \%$ (H. ${ }^{18} / 2$ ), Skærbæk $6 \%$ og forhøjer Reservefonden til $25 \%$ af Aktiekapitalen (H. ${ }^{4}, 2$, Av. ${ }^{21 / 3}$ ), Graasten $8 \%$ (H. ${ }^{7} / 2$ ), Rødding $61 / 2 \%$. Den har voksende Indskud (H. $\left.{ }^{13} / 2,{ }^{2} / 3\right)$. Folkebanken for Als og Sundeved $6 \%$. Den har $320,000 \mathrm{Kr}$. Reservefond (H. ${ }^{19 / 2} / 2$, ${ }^{13} / 3$ ). Haderslev Banks Indskud er vokset med 843,180 Kr. Den ser ret lyst paa Fremtiden (H. $\left.{ }^{4} / \mathrm{s}\right)$. Den nordslesvigske Folkebank giver $6 \%$ Udbytte (H. $\left.{ }^{10 / 3}\right)$. Haderslebener Creditbank giver $8 \%$ og har 107 Mill. Kr. Omsætning mod 123 Mill. Aaret før $\left(\mathrm{H}^{20} / 3\right)$. Tønder Landmandsbanks Omsætning er vokset, ogsaa dens Indskud (H. ${ }^{22 / 2},{ }^{16} / 3$ ). Kreditorerne i den likviderende Nordslesvigs Bank faar fuld Dækning (H. ${ }^{18} / 5$ ).

Af $S$ p a rekas serne har Frøs- og Kalvslund Herre. ders 200,000 Kr. forøget Indskud. Den har nu 2,101,334 Kr. (H. ${ }^{10} / 8$ ), Nørborg 2,069,632 Kr., Sønderborg 9,66 Millioner (vokset med 860,000) (H. ${ }^{20} / 8$ ). I det hele udgør Sparekasseindskuddene i Sønderjylland nu godt 45 Millioner $\mathrm{Kr}$. (H. ${ }^{17 / 8)}$. Sparekassernes Udlaansrente er $1 \%$ højere end i København, 0,56 \% højere end i Nørrejylland ( $\left.\mathrm{H} .{ }^{21 /} / \mathrm{s}\right)$.

$\mathrm{L}$ a a $\mathrm{n}$ ek a s e $\mathrm{n}$ for Sønderjylland har hidindtil til 8482 Laanere udlaant 21,536,360 $\mathrm{Kr}$., hvoraf 9,472,484 $\mathrm{Kr}$. er tilbagebetalt (H. $\left.\% / 1,{ }^{10} / 1\right)$.

Agerskov Sogn har siden 1926 haft lidt Frem g a n g i skattepligtig Indkomst. Der er nu flere med Formuefremgang og Balance og færre med Tilbagegang (H. ${ }^{1 / 3}$ ). Alligevel siger Erhvervsudvalget i sin Beretning, at $\mathrm{V}$ a $\mathrm{nske-}$ ligh edern e fremdeles er større her nede end i Kongeriget, men Ordningen af Realkreditten er gunstig, og der er Bedring i Renteforholdene (H. $8 / 2$ ). 
Sønderjyllands K reditforen ing har udlaant ialt $157,139,100 \mathrm{Kr}$. til 8000 Laanere; deraf har 263 tilbagebetalt $5,217,700 \mathrm{Kr}$., og ekstraordinært er der afbetalt 7,296,700. Forholdene er i det hele i Bedring (H. $\left.{ }^{22} / 10\right)$.

$\mathrm{H}$ y p otek la a n ef ond et har ${ }^{28 / 28}$ udbetalt 886 Laan til $5,074,500 \mathrm{Kr}$. $\left(\mathrm{H},{ }^{30} / 10\right)$. Det har ialt udlaant $11^{1 / 2}$ Million (H. ${ }^{31} / 10$ ).

51 Gaarde og 10 Huse, der er bleven s o l g t i 1928, har gennemsnitligt kostet mere end Vurderingssummen (H. ${ }^{15} / 11$ ).

Skærbæk Kommune a rve d e 150,000 Dollar efter Jens Nissum, der var født der i Sognet $\left(H,{ }^{10} / 11\right)$.

Sønderjydsk Fond har i 1928 disponeret over $289,854 \mathrm{Kr}$. (H. $\left.{ }^{5} / \mathrm{s}\right)$.

Død s b o e r n e hernede er magre. Der er næsten intet at indberette om dem til Landsoverskatteraadet (H. ${ }^{24},(1,25 / 1)$.

e) S a m k vem.

Haderslev A $\mathrm{m}$ tsbaner havde et Underskud af $377,000 \mathrm{Kr}$. (H. $\left.{ }^{16} / 10\right)$. De alsiske bragte $12,000 \mathrm{Kr}$. Driftsunderskud. Godstrafikken har svigtet (H. $\left.{ }^{5 / 9}\right)$. I Haderslev Amt ophæves nogle Bilruter $\left(\mathrm{H} .{ }^{26} / 2\right)$. Aabenraa Amt bygger $\mathrm{V}$ ejen Lundsbjerg-Tinglev, befæster Haderslevvejen og gør flere andre Strækninger færdig (H. ${ }^{10} / 4$ ). Blandt de færdiggjorte er Vejen til Rødekro (H. ${ }^{18 / 7}$ ). Sønderborg Amt har siden Genforeningen bygget ca. $60 \mathrm{~km}$ Amtsveje (H. ${ }^{11 / 9}$ ). I Tønder Amt brolægges $6200 \mathrm{~m} \mathrm{Vej}$ (H. ${ }^{23} / 3$ ). I det hele havde Amterne $1 / 429$

\begin{tabular}{lcc}
\multicolumn{1}{r}{ km } & Landevej & deraf blolagt \\
Aabenraa & 164 & $0,548 \mathrm{~km}$ \\
Haderslev & 266 & $2,312 ~ "$ \\
Sønderborg & 104 & $0,054 "$ \\
Tønder & 296 & $0,936 ~ "$
\end{tabular}

En tysk Vejinspektør kalder vort Vejarbejde bedre og mere radikalt end det tyske. $\left(\mathrm{H}^{3}{ }^{3 / 12}\right)$. Motorafgiften til Sønderjylland blev 3,143,880 Kr. (H. ${ }^{17} / 6$ ).

\section{Kommunalt.}

Sønderborgs B u d g e t er paa 1,293,054 Kr. eller 116,718 Kr. mindre end sidste Regnskabsaar. (H. $\left.{ }^{10}{ }_{11}^{\prime}\right)$. Aabenraas 
er paa $620,700 \mathrm{Kr}$., Skattebehovet, der $25 / 26$ var $771,598 \mathrm{Kr}$. bliver ${ }^{29} /$ so $^{4} 62,000$. (H. ${ }^{18} / 1$ ). I Haderslev skal der udskrives 690,000 Kr. i Skat, det laveste B Haderslev Amts Budget for ${ }^{30} / \mathbf{3 1}$ er paa $1,100,880 \mathrm{Kr}$. ligesom i Fjor, 111,000 lavere end Regnskabet ${ }^{28} / 20$. (H. $3 / 12$ ). L i gning s procenten blev i Haderslev 7,8. Det er 5. Aar, den gaar nedad $\left(\mathrm{H},{ }^{10} / 3\right.$ ) i Aabenraa 8,5 ligesom i Fjor (H. ${ }^{27} / 3$ ) i Sønderborg $11 \bmod 12,4$ i Fjor. (H. ${ }^{26} / 3$ ). I Haderslev valgtes Sagfører Thulstrup til Borgmester. (H. ${ }^{12 / 2}$ ).

\section{Menighedslivet.}

De kirkelige G.ru ndbyrder skal afløses. De beløber sig dog kun til $2360 \mathrm{Kr}$. (H. ${ }^{7 / 2}$ ). De sønderjydske Kirker faar 40,000 Kr. aarlig Statsstøtte i 10 Aar. (H. ${ }^{13} / 7$ ). De tyske Menighedsraadsmedlemmer har andraget paa at overlade Præsteindstillingsretten til henholdsvis de danske eller tyske Medlemmer alene. Ministeriet har dog afslaaet det, da det udelukker dem, der ikke tager national Stilling. Ogsaa andre Grupper kunde jo sa:i kræve Retten overladt. (H. ${ }^{y}(y)$. Menighedsraadsforeningen kræver mere Selvstyre. (H. $\left.{ }^{30} / 5\right)$. 40 Præsteembeder agtes s a mmenlagt. (H. $\% / \gamma)$ Der indsættes en ny Tredje præst i Sønderborg. (H. $\left.{ }^{21 / 1} / 1\right)$. Den nye Kirke i Rinkenæs kan bygges for $70,000 \mathrm{Kr}$., som man har. (H. ${ }^{28} / 9$ ). Den ${ }^{10} / 11$ fejrede $\mathrm{B}$ ov lund Frimenighed $\sin 50$ Aarsdag. (H. $\left.{ }^{15} / 11,{ }^{20 / 11}\right)$.

\section{Oplysning.}

70 unge Mennesker fra Nordslesvig og 46 fra Sydslesvig faar Støtte af Skoleforeningen til Skoleophold. (H. ${ }^{20} / 3$ ). Den ${ }^{31} / 1228$ var der 4855 skole pligtige Børn i A a ben ra a Amt. Deraf gik 4057 i dansksprogede og 300 i tysksprogede Klasser. I de tyske Privatskoler gik 442 Børn. (H. 8/4). I Tø n d e r Amt gaar 3853 Børn i danske og 975 i tyske Skoler. Børneantallet er steget med 71. Tyskernes Procentandel er 20,19. Af de tysk underviste Børn gaar 70 i Privatskoler. (H. ${ }^{15} / \%$ ). 1921 gik i de tvesprogede Skoler i Tønder Amt 1000 Børn til tysk 960 til dansk Undervisning. 1928 var Tallene henholdsvis 905 og 1126. (Av. ${ }^{15} /$ ). 1929 var det tyske Procenttal 19,99. (Ber. om Skolevæsenet i Tønder Amt 1929). I Haderslev By fik ${ }^{28 / 29}$ 
1302 dansk og 437 tysk Undervisning. (Ber. fra Haderslev komm. Skolevæsen ${ }^{28 / 29}$ ).

Ved Statsskolerne tog 1928 følgende Antal Eksamen: $\mathrm{T} ø \mathrm{n}$ de $\mathrm{r} 10$ Studentereksamen, 19 Realeksamen, H a d e rs l e v 28 St., 34 R., Sønd e rborg 20 St., 20 R. (Skolernes Aarsberetninger).

\section{Ret og Forvaltning.}

Kaptajn Le mbourn (se under 1) fik ved Benaadning sin Tugthusstraf forvandlet til Fæstningsarrest. (H. ${ }^{30} / 3$ ). Sagfører Tods en i Tønder sigtes for Bedrageri (H. ${ }^{2} / 2$ ) skaffer Dækning for Beløbet $\left(\right.$ H. $\left.{ }^{15} / 2\right)$ men forlader dog senere Byen og Landet. En fuld Mand slaar en ung Skovfogedlærling ihjel ved Farversmølle ved Aabenraa (H. ${ }^{10 / 8}$ ) og idømmes 18 Maaneders Forbedringshus. (H. $1 / 11$ ).

\section{Pressen.}

De k o n s e r vati ve Blade i Sønderjylland gaar sammen med "Kolding Avis" op i en Aflægger af "BerlingskeTidende«, der fra $1 / 9$ udkommer i Kolding under Navn af "Jydske Tidende«. (H. $\left.{ }^{2} / 9\right)$.

"H e j m d a l« holdt $1 / 1050$ Aars Jubilæum, ved hvilker Lejlighed der gaves en Udsigt over dens Udvikling. ( $\mathrm{H}$. 1/10). "Flensborg Avis" fejrede samtidig 60 Aars Jubilæum. (Av. 1/10). Hejmdal udvidede sin Aktiekapital fra 100,000 til $150,000 \mathrm{Kr}$. (H. ${ }^{2} / 10$ ).

\section{Personligt.}

Redaktør Nis Petersen, Haderslev, blev 70 Aar 1/2, Stiftsprovst Hjortkjær, Haderslev 60 Aar ${ }^{28} / 8$. Kasper Jensen, 70 Aar. (H. ${ }^{22} / 11$ ).

Blandt dem, der døde 1929, maa nævnes Fru H. V. Clausen $3 / 2$, Borgmester Christensen, Haderslev ${ }^{4} / 2$, Hans Tychsen, Frøslev 15/2, Pastor Rossen, Agerskov ${ }^{28} / 2$, Købmand Jørgen Petersen, Haderslev ${ }^{8} / 6$, Pastor Rosenstand, V. Vedsted $1 / 9$, Hans Rolskov, Toftlund $8 / 9$, C. Finnemann, Christiansfeld $8 / 10$, Hans Gram, Vojens $23 / 11$, Kammerherre Stemann, Haderslev ${ }^{27} / 12$, Mejeriejer Nissen, Haderslev ${ }^{20} / 12$.

Magnus Schmidt forsvarer ved Sorbonnen i Paris sir Doktordisputats, der belønnes med 1. Karakter. (H. ${ }^{31} /{ }^{19} / 2$ ). 


\section{Andre Sager.}

Det kan ikke med Sikkerhed siges, at Vestkysten hæver sig. (H. ${ }^{25} / 1$ ). Flensborg har 67 Skibe paa 86,566 Bruttotons. (Av. ${ }^{25} / 1$ ). I Hessel ved Aabenraa har ligget en Bispegaard, som nævnes 1462. (H. ${ }^{1 / 2}$ ). Haderslev Sangforening holder 60 Aars Jubilæum. (H. ${ }^{29} / 6$ ). Tønderegnens Folkeliv filmes af Folkemuseet. $\left(\mathrm{H} .{ }^{19} / \mathrm{i}\right)$. Nationalmuseet arbejder stærkt her nede. Det er nu næsten færdigt. (H. ${ }^{26} / 7$ ). Stednavneudvalget har indsamlet 50,000 Stednavne fra Sønderjylland. $\left(\mathrm{H} .{ }^{28} / 8\right.$ ). I Aabenraa Amt er der foretaget en Række Fredninger. (H. ${ }^{18} / 8$ ). Aarø Kalv fredes. (H. ${ }^{18} / \mathrm{g}$ ). Olmersdiget har efter la Cour været et virkeligt Grænseværn. Det er $11-12 \mathrm{~km}$ langt. (H. $\left.{ }^{19} / \mathrm{g}\right)$. Varnæs Mose agtes fredet. (H. $\left.{ }^{17} / 10,{ }^{18} / 10,{ }^{21} / 10\right)$. Bjergskov ved Søgaard fredes. (H. "/12). V. la Cour foreslaar Museet i Haderslev gjort til forhistorisk Museum for hele Sønderjylland, Sønderborg gjort til et Museum for Hertugtiden og de nationale Kampe. Købstadkulturen samles i Aabenraa og Bondekulturen ligeledes paa et Sted. (H. ${ }^{18} / 12$ ). 